\title{
BUILDING 594 WASTE ION EXCHANGE FACILITY FINAL SURVEY REPORT
}

\section{ARGONNE NATIONAL LABORATORY ARGONNE, ILLINOIS}

\author{
Prepared by \\ D.C. Geraghty \\ Environment Safety and Health Division \\ Health Physics Section \\ Argonne National Laboratory \\ Argonne, Il 60439
}

October 1998 


\section{BUILDING 594 WASTE ION EXCHANGE FACILITY FINAL SURVEY REPORT}

\section{ARGONNE NATIONAL LABORATORY ARGONNE, ILLINOIS}

October 1998

Characterization Performed and Report Prepared by

Health Physics Section

Environment, Safety and Health Division

Argonne National Laboratory

Site Remediation and Report Team:

Dolores Geraghty

Jeff Dukes

Joseph Cooney

Dave Garbin

Jim Byrnes

Dave Kuzma

Barbara Richardson

Glen Harris 


\section{TABLE OF CONTENTS}

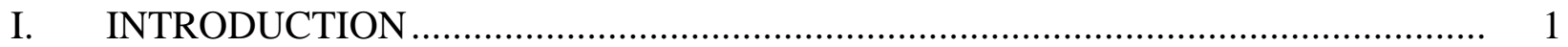

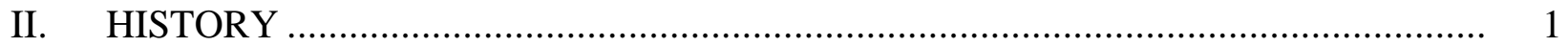

III. INSTRUMENTATION, CALIBRATION ……................................................... 2

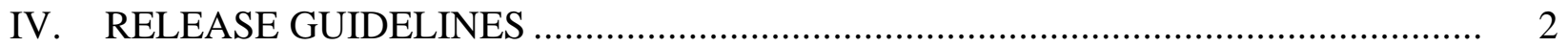

V. OVERVIEW OF THE DECONTAMINATION

AND DEMOLITION ACTIVITIES …………..................................................... 9

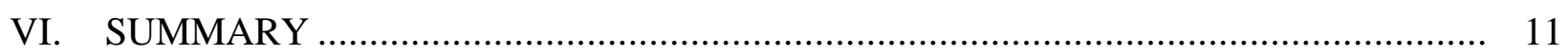

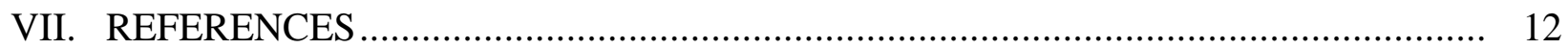

APPENDIX A: Instrument Calibration \& Operational Check Records.................................. A-1

APPENDIX B: Unrestricted Release Documents ………................................................. B-1

APPENDIX C: Direct \& Smear Survey Results ……..................................................... C-1

\section{TABLES}

1 Component Numbers and Names ............................................................................ 5

2 Instruments Used for Decontamination and Demolition............................................... 6

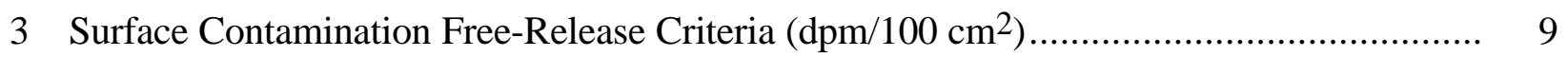




\section{FIGURES}

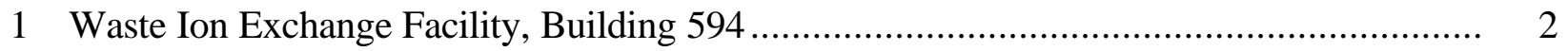

2 Building 594 Piping to Adjacent Facilities ........................................................... 3

3 Building 594 Ion Exchange Piping \& Equipment ................................................. 4

4 NE Technology Model Electra with $100 \mathrm{~cm}^{2}$ Detector for Measuring

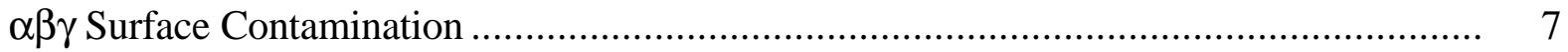

5 Tennelec APC MII Smear Counting System .................................................... 7

6 Dual Alpha Beta Radioactivity Assay System (DABRAS)

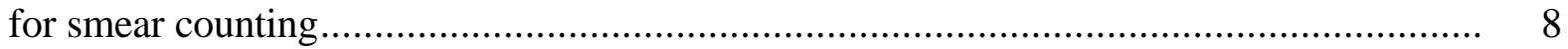

7 Eberline PRM-5-3 with PG-2 Scintillation Detector $\left(2^{\prime \prime} \times 2 \mathrm{~mm}\right.$ thick $\mathrm{NaI}$ detector $)$.

8 Health Physics Survey of the Cation Exchange Vessel, Mixed Bed Exchange Vessel and Equipment.

9 Health Physics Survey of Piping from beneath Building 594 Concrete Pad .................... 11 


\section{BUILDING 594 WASTE ION EXCHANGE FACILITY FINAL SURVEY REPORT}

\section{INTRODUCTION}

The decontamination and demolition of the Waste Ion Exchange Facility (Building 594) was completed in September, 1998. Descriptions of these processes are included in this Final Report. The following information is included:

- History of the Waste Ion Exchange Facility

- Instruments and Calibrations

- Overview of the Decontamination and Demolition Activities Performed

- Results of Health Physics Final Surveys

- Summary of Completion Status

\section{HISTORY}

The Waste Ion Exchange Facility building 594, (formerly 579) was a prefabricated, galvanized, metal building, $20 \mathrm{ft}$. wide by $32 \mathrm{ft}$. long by $14 \mathrm{ft}$. high (see Figure 1). It was constructed in the 1950's to enclose the waste ion exchange system that was used to process waste fluids from a collecting lagoon. The building contained ion exchange equipment that was connected to the collecting lagoon, equalization tanks, and Building 592 (formerly Bldg. 575) distribution pit by underground piping (see Figure 2). There were influent lines on the east side of the building and an effluent line on the north side of the building.

The main components inside the Waste Ion Exchange Facility were the ion exchange vessels and associated piping located on the east side of the building (see Figure 3). The numbered components are identified in Table 1. Normal access to the facility was through doorways located on both the north and south ends of the building. 


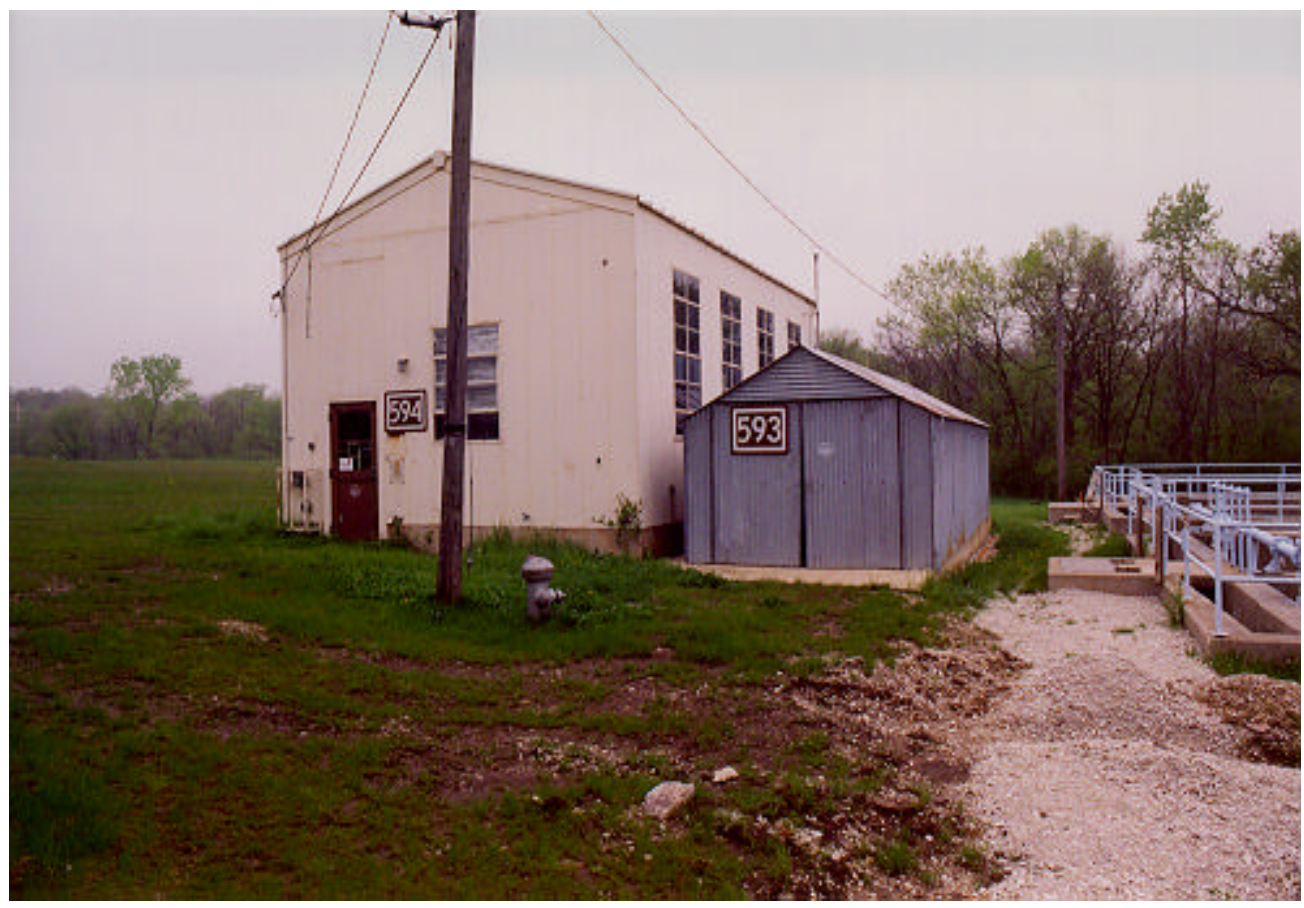

FIGURE 1 Waste Ion Exchange Facility, Building 594

\section{INSTRUMENTATION, CALIBRATION}

Instruments were chosen to assure that the MDAs for the selected instrument/technique was less than the release criteria. A listing of the principal instruments used and their typical MDAs is given in Table 2. Photographs of the principal instruments used for final surveys are shown in Figures 4 through 7 . Instrument calibration records and daily instrument check records are included in Appendix A.

\section{RELEASE GUIDELINES}

Table 3 is a summary of the free-release criteria associated with surfaces contaminated with radioactive materials. The release criteria for Transuranics and ${ }^{90} \mathrm{Sr}$ were used for the unrestricted release of nonporous materials from this project. 


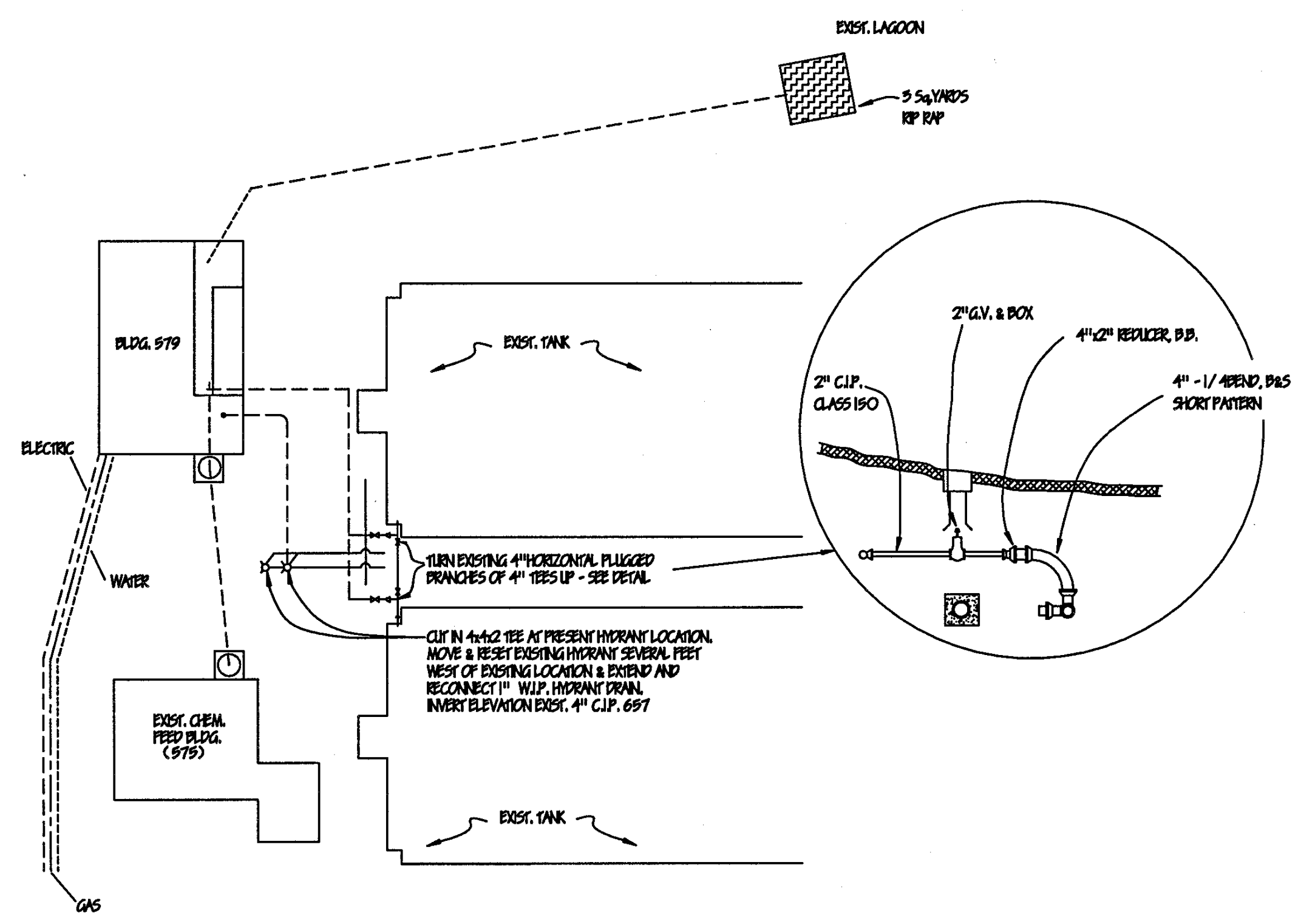

FIGURE 2 Building 594 Piping to Adjacent Facilities 


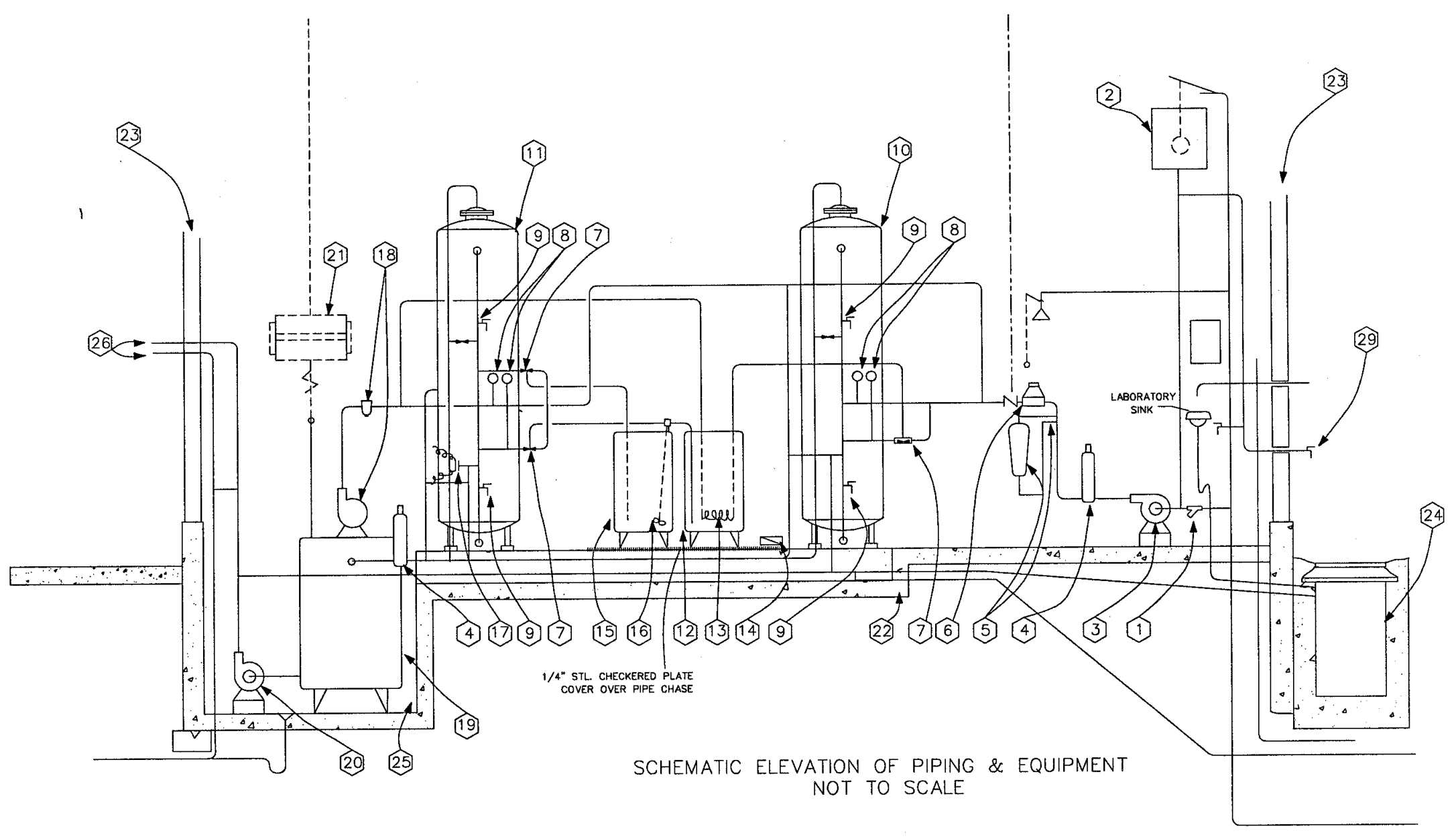

\section{FIGURE 3 Building 594 Ion Exchange Piping \& Equipment}


TABLE 1 Component Numbers and Names (The component numbers and names show in Figure 3.)

\begin{tabular}{ll}
\hline Number & \multicolumn{1}{c}{ Name } \\
\hline & \\
1 & Strainer with Monel Screen \\
2 & 50 gal Surge Tank \\
3 & Forwarding Pump \\
4 & Influent \& Effluent Filters \\
5 & Flow Indicator \\
6 & Water Meter \\
7 & Acid \& Caustic Ejectors \\
8 & Inlet \& Outlet Pressure Gauges \\
9 & Inlet \& Outlet Sampling Cocks \\
10 & Cation Exchange Vessel \\
11 & Mixed Bed Exchange Vessel \\
12 & Acid Regenerant Tank \\
13 & Lead Grid Agitator \\
14 & Acid Foot Pump \\
15 & Caustic Regenerant Tank \\
16 & Caustic Mixer \\
17 & Conductivity Indicator \\
18 & Blower \\
19 & Closed Drain Tank \\
20 & Drain Pump \\
21 & Filter \\
22 & Trench \\
23 & Building \\
24 & Catch Basin \\
25 & Pit \\
26 & Effluent Pipe \\
27 & Miscellaneous items in the building \\
28 & Exchanger Testing Equipment \\
29 & Influent Pipe \\
30 & Air Samples \\
\hline &
\end{tabular}


TABLE 2 Instruments Used for Decontamination and Demolition

\begin{tabular}{|c|c|c|c|c|c|}
\hline Purpose & Instrument & $\begin{array}{c}\text { Detector } \\
\text { Description } \\
\end{array}$ & $\begin{array}{c}\text { Measurement } \\
\text { Units } \\
\end{array}$ & Typical Characteristics & $\begin{array}{l}\text { Typical } \\
\text { MDA }^{\mathbf{a}}\end{array}$ \\
\hline Total Surface $(\alpha)$ & $\begin{array}{l}\text { NE Technology, } \\
\text { Ltd. ELECTRA }\end{array}$ & $\begin{array}{c}\text { Dual Scintillator } \\
100 \mathrm{~cm}^{2} \text { sampling area } \\
0.5 \mathrm{mg} / \mathrm{cm}^{2}\end{array}$ & cpm & $\begin{array}{l}21 \%{ }^{241} \text { Am efficiency, } \\
30 \mathrm{sec} \text { residence time, } \\
\leq 7 \mathrm{cpm} \text { background }\end{array}$ & $98 \mathrm{dpm}$ \\
\hline Total Surface $(\beta-\gamma)$ & $\begin{array}{l}\text { NE Technology, } \\
\text { Ltd. ELECTRA }\end{array}$ & $\begin{array}{c}\text { Dual Scintillator } \\
100 \mathrm{~cm}^{2} \text { sampling area } \\
\sim 6 \mathrm{mg} / \mathrm{cm}^{2}\end{array}$ & cpm & $\begin{array}{l}29 \%{ }^{90} \mathrm{Sr}-\mathrm{Y} \text { efficiency, } \\
30 \mathrm{sec} \text { residence time, } \\
\leq 400 \mathrm{cpm} \text { background }\end{array}$ & $410 \mathrm{dpm}$ \\
\hline Removable Surface $(\alpha)$ & Tennelec APC & $\begin{array}{c}\text { Gas Proportional } \\
5 \mathrm{~cm} \mathrm{dia.} \\
0.1 \mathrm{mg} / \mathrm{cm}^{2}\end{array}$ & $\mathrm{cpm}$ & $\begin{array}{c}30 \%{ }^{241} \text { Am efficiency, } \\
2 \text { min count time, } \\
\leq 1 \mathrm{cpm} \text { background }\end{array}$ & $17 \mathrm{dpm}$ \\
\hline Removable Surface $(\beta-\gamma)$ & Tennelec APC & $\begin{array}{c}\text { Gas Proportionall } \\
5 \mathrm{~cm} \mathrm{dia.} \\
0.1 \mathrm{mg} / \mathrm{cm}^{2}\end{array}$ & $\mathrm{cpm}$ & $\begin{array}{l}42 \%{ }^{90} \mathrm{Sr}-\mathrm{Y} \text { efficiency, } \\
2 \text { min count time, } \\
\leq 40 \mathrm{cpm} \text { background }\end{array}$ & $86 \mathrm{dpm}$ \\
\hline Removable Surface $(\alpha)$ & DABRAS & $\begin{array}{c}\text { Gas Proportional } \\
200 \mathrm{~cm}^{2} \\
0.4 \mathrm{mg} / \mathrm{cm}^{2}\end{array}$ & $\mathrm{cpm}$ & $\begin{array}{l}27 \%{ }^{241} \text { Am efficiency, } \\
2 \text { min count time } \\
\leq 2 \mathrm{cpm} \text { background }\end{array}$ & $18 \mathrm{dpm}$ \\
\hline Removable Surface $(\beta-\gamma)$ & DABRAS & $\begin{array}{c}\text { Gas Proportional } \\
200 \mathrm{~cm}^{2} \\
0.4 \mathrm{mg} / \mathrm{cm}^{2}\end{array}$ & cpm & $\begin{array}{l}49 \%{ }^{90} \mathrm{Sr}-\mathrm{Y} \text { efficiency, } \\
2 \text { min count time, } \\
\leq 270 \mathrm{cpm} \text { background }\end{array}$ & $86 \mathrm{dpm}$ \\
\hline Find Elevated $x-\gamma$ & $\begin{array}{l}\text { Eberline } \\
\text { PRM 5-3 with } \\
\text { PG-2 detector }\end{array}$ & $\begin{array}{c}5 \mathrm{~cm} \text { diameter } \times 2 \mathrm{~mm} \\
\text { thick } \mathrm{NaI}(\mathrm{Tl})\end{array}$ & cpm & $\begin{array}{l}2 \mathrm{sec} \text { residence time } \\
500 \mathrm{cpm} \text { background }\end{array}$ & $\begin{array}{c}1500 \mathrm{cpm} \\
\text { net }\end{array}$ \\
\hline
\end{tabular}

a Note: The typical MDA for the NE Technology, Ltd. ELECTRA, the Ludlum Model 3 and the Eberline PRM 5-3 with a PG-2 detector is based upon the use of audio output to enhance the discernment of recordable measurements. 


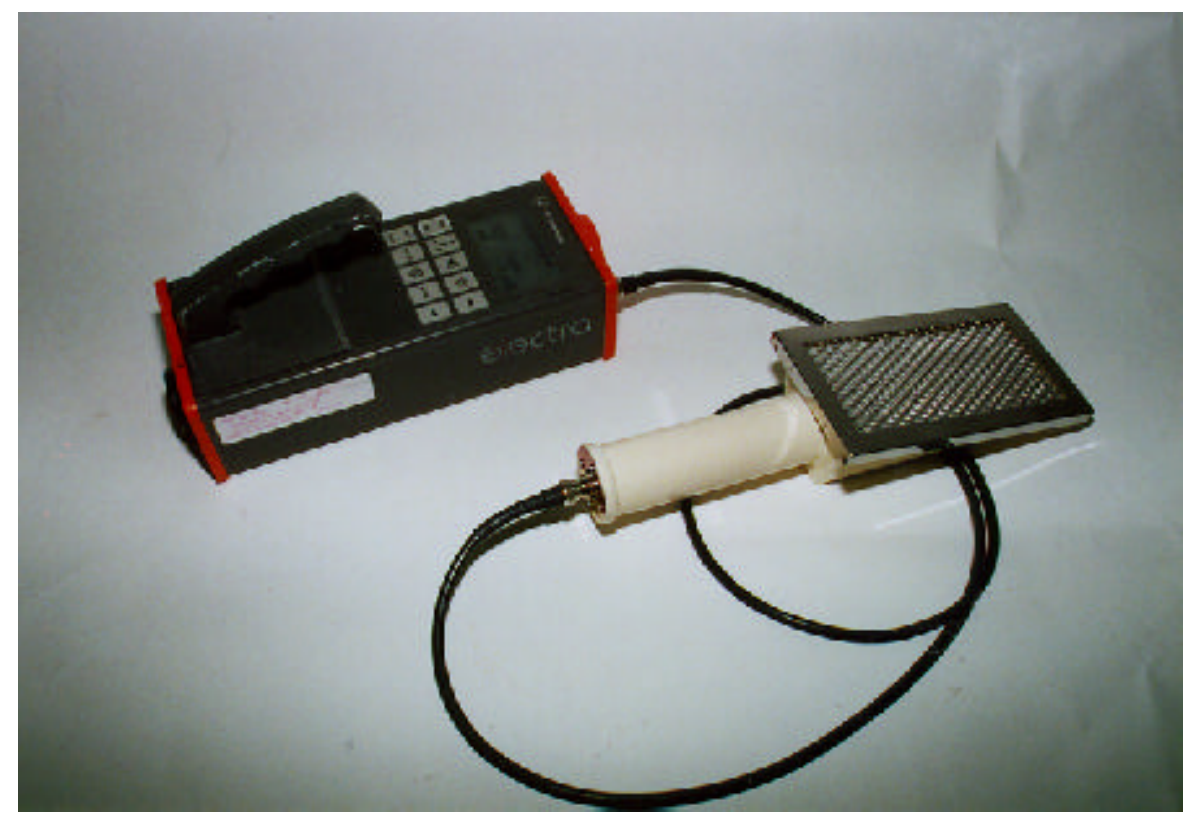

FIGURE 4 NE Technology Model Electra with $100 \mathrm{~cm}^{2}$ Detector for Measuring $\alpha \beta \gamma$ Surface Contamination

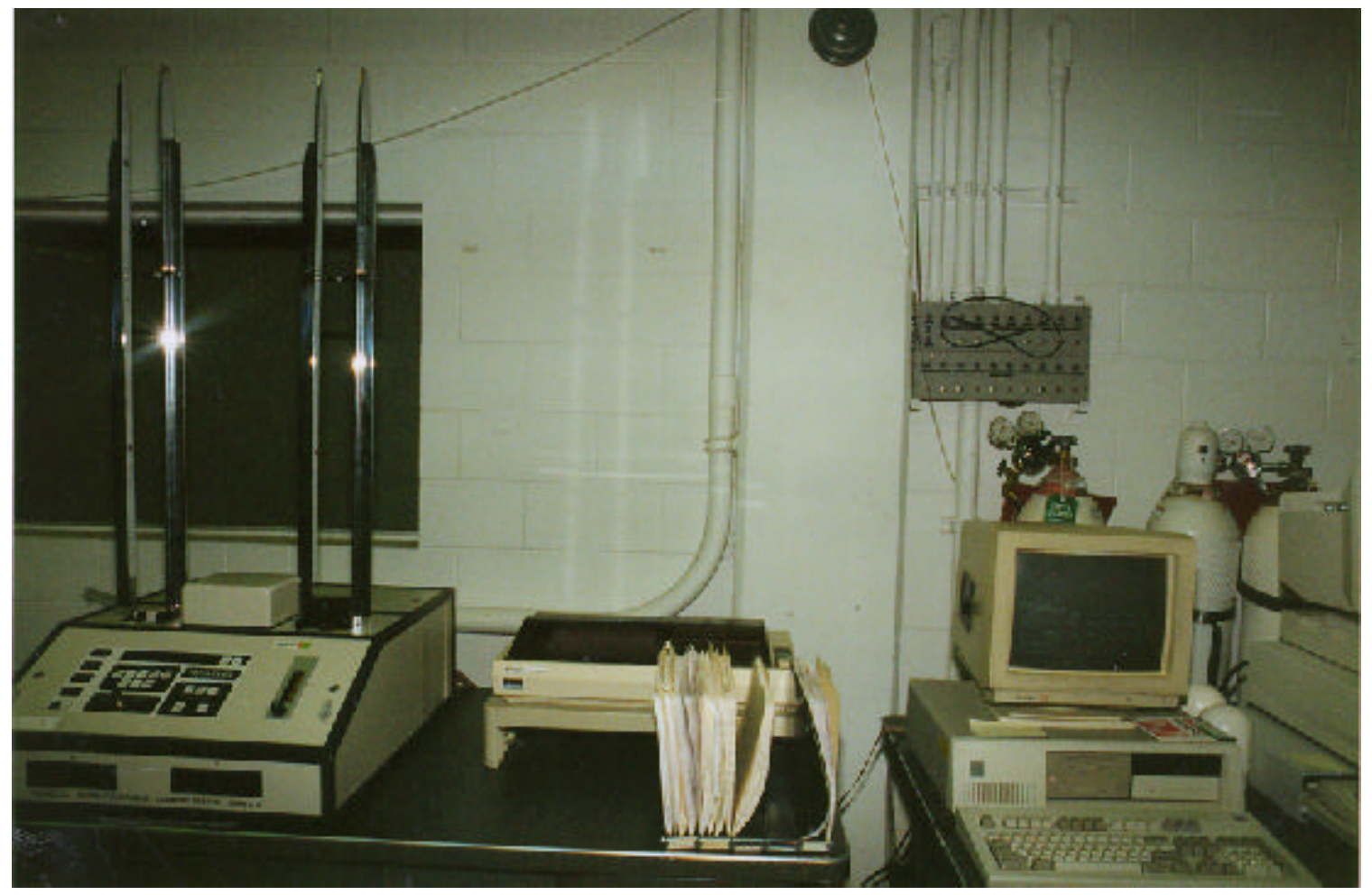

FIGURE 5 Tennelec APC MII Smear Counting System 


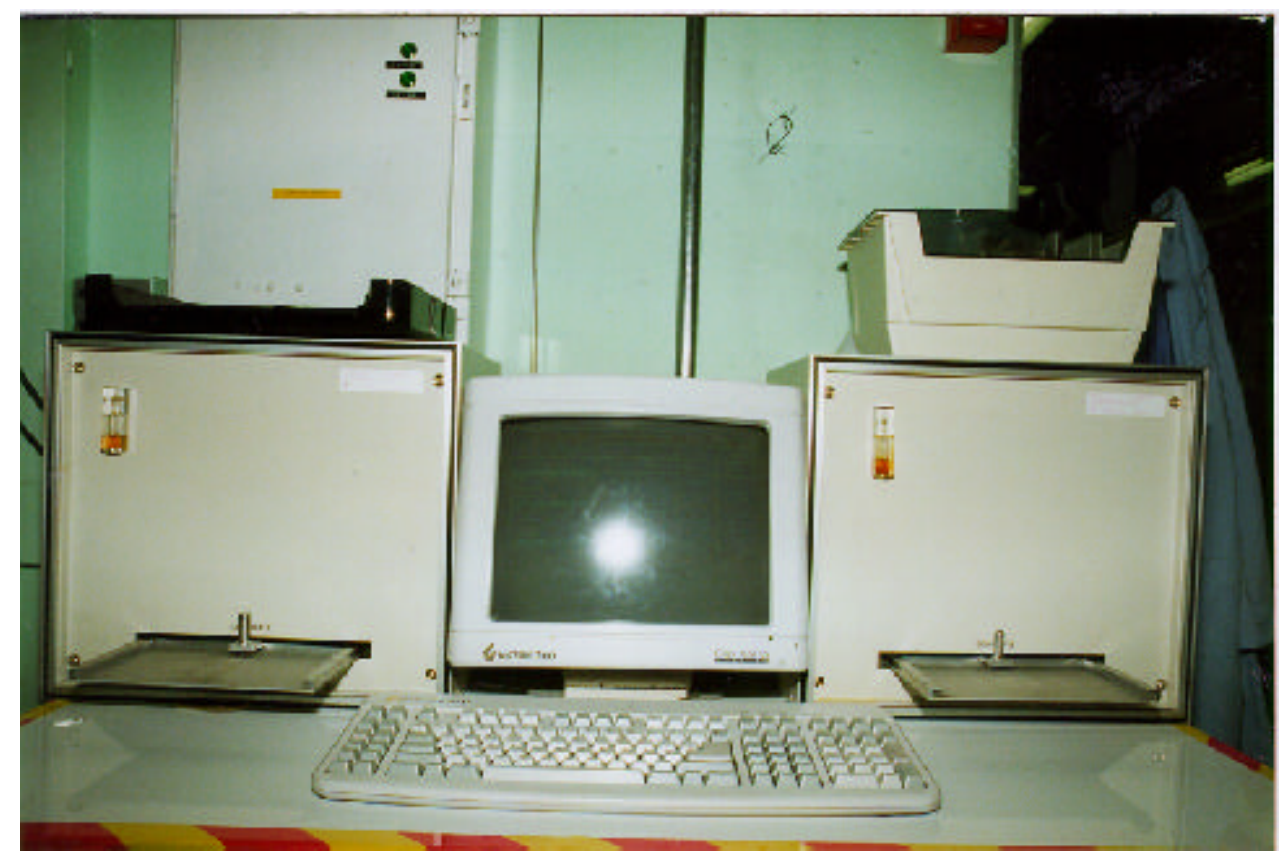

FIGURE 6 Dual Alpha Beta Radioactivity Assay System (DABRAS) for smear counting

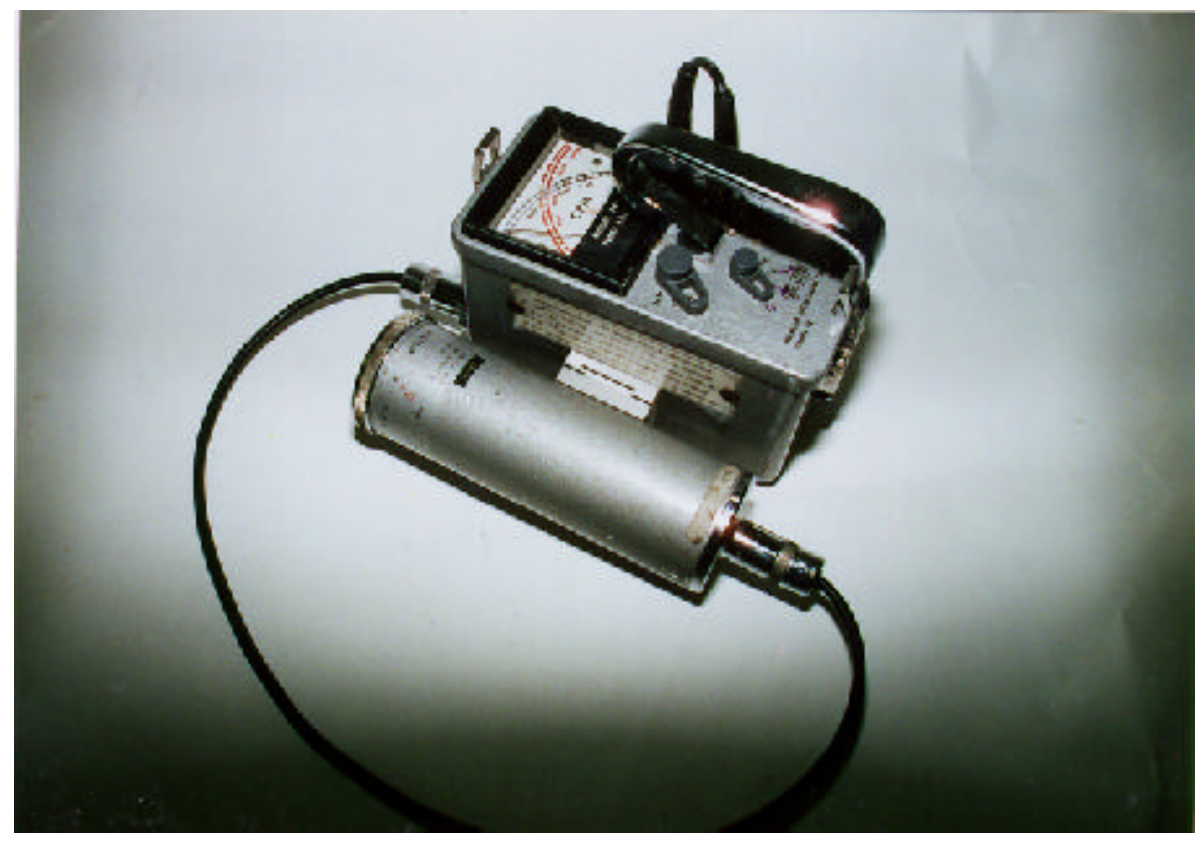

FIGURE 7 Eberline PRM-5-3 with PG-2 Scintillation Detector $\left(2^{\prime \prime} \times 2 \mathrm{~mm}\right.$ thick $\mathrm{NaI}$ detector $)$ 
TABLE 3 Surface Contamination Free-Release Criteria $\left(\mathrm{dpm} / \mathbf{1 0 0 \mathrm { cm } ^ { 2 } )}\right.$

\begin{tabular}{lccc}
\hline \multicolumn{1}{c}{ Total (fixed and removable) Radionuclides } & Average & Maximum & Removable \\
\hline $\begin{array}{l}\text { Transuranics, I-125, I-129, Ra-226, Ac-227, Ra-228, Th-228, } \\
\text { Th-230, Pa-231 }\end{array}$ & 100 & 300 & 20 \\
$\begin{array}{l}\text { Th-Natural, Sr-90, I-126, I-131, I-133, Ra-233, Ra-224, U- } \\
\text { 232, Th-232 }\end{array}$ & 1,000 & 3,000 & 200 \\
$\begin{array}{l}\text { U-Natural, U-235, U-238, and associated decay product, alpha } \\
\text { emitters }\end{array}$ & 5,000 & 15,000 & 1,000 \\
\begin{tabular}{l} 
Beta-gamma emitters (except Sr-90) \\
\hline
\end{tabular} & 5,000 & 15,000 & 1,000 \\
\hline
\end{tabular}

\section{OVERVIEW OF THE DECONTAMINATION AND DEMOLITION ACTIVITIES}

Major tasks performed during the decontamination and demolition of the Waste Ion Exchange Facility were as follows:

1. Removal of all excess equipment: Lockers, shelving, motors, copper pipe, and miscellaneous materials were surveyed by the ANL-E ESH Health Physics Section personnel and released for recycling or disposal as trash. All external piping from the floor drains were removed and surveyed for release.

2. Resin was removed from the Cation Exchange Vessel and the Mixed Bed Exchange Vessel. The resin was packaged into 55 gallon drums as low-level radioactive waste for disposal by Waste Management Personnel.

3. The Cation Exchange Vessel and the Mixed Bed Exchange Vessel (See Figure 8) were then removed, placed on their sides and vacuumed by WMO. The tanks were surveyed, size reduced, and disposed of as clean scrap metal.

4. All motors, piping, retention tank, and associated equipment were surveyed and removed. A hole had to be cut into the retention tank to remove the water which was pumped by WMO into a dempster tank. This water was then processed through WMO's retention tank water treatment system. The retention tank was then surveyed again and released as clean scrap.

5. HEPA filter material was surveyed as clean and disposed of by WMO. 


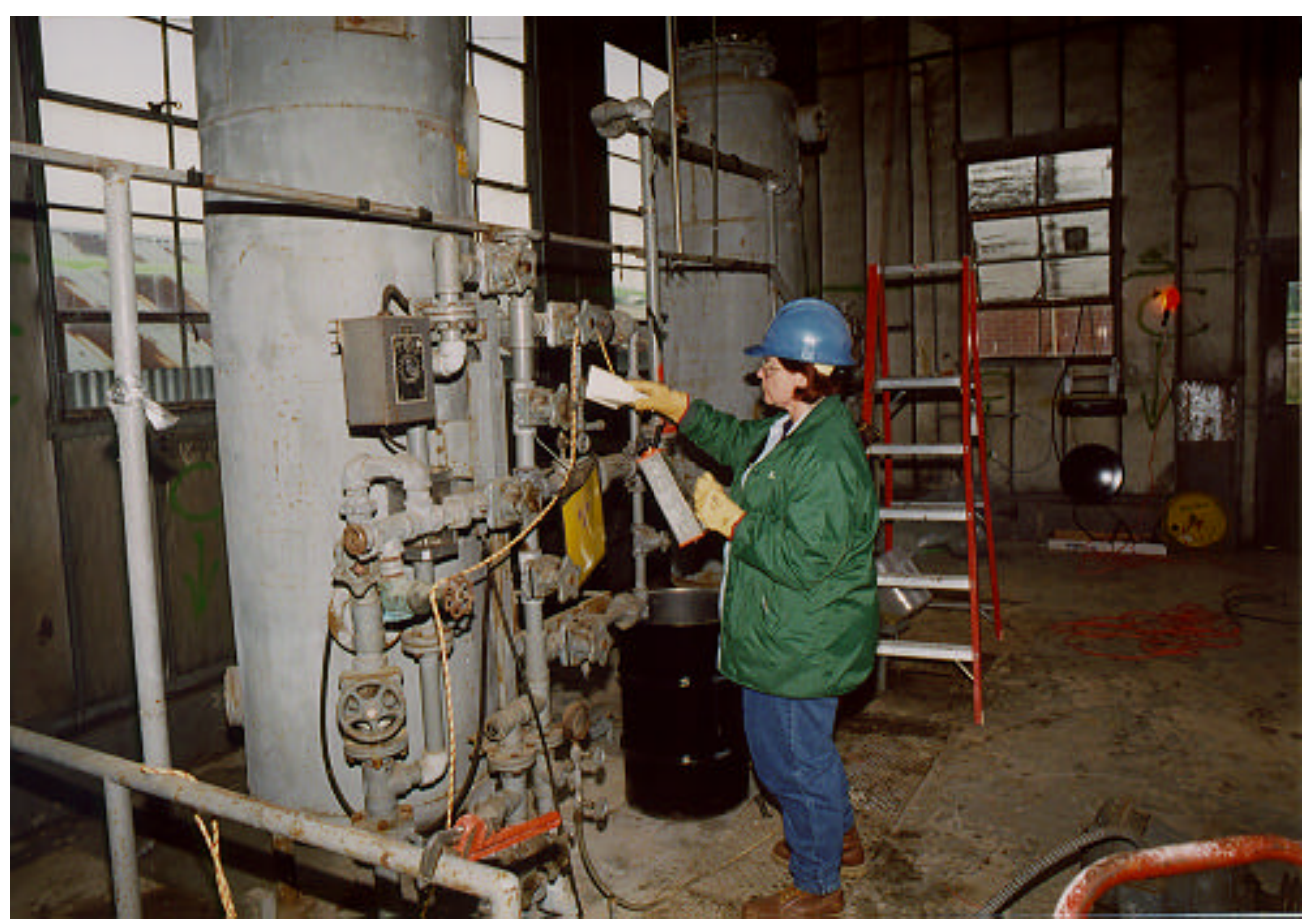

FIGURE 8 Health Physics Survey of the Cation Exchange Vessel, Mixed Bed Exchange Vessel and Equipment

6. Catch Basin: The catch basin (\#24 in Figure 3) was left in place. The piping from the basin is connected to a laboratory tank and equalization tank in building 592 (575 in Figure 2). A water sample from the catch basin was less than ten times the site release criteria. As found during the characterization, the catch basin had $\gamma$ activity above the ambient background. The catch basin sample taken during the characterization appeared to contain only naturally occurring radionuclides. The activity levels are below the unrestricted release criteria. Therefore, the catch basin is released for unrestricted use.

7. Tritium Survey: Four smears were taken from areas in Building 594 that were deemed to be most likely to contain residual tritium (Appendix B ). Values for these smears were less than $10 \%$ of the unrestricted release criteria for betagamma emitters of $1,000 \mathrm{dpm} / 100 \mathrm{~cm}^{2}$.

8. No contamination was detected on the final surveys of the walls, windows, doors, ceilings, exhaust pipe from ceiling. The building and associated concrete was released for demolition by memo to E. Wiese (TD) from C.M. Sholeen (ESH-HP), dated July 30, 1998 ( Appendix B).

9. Building 594 and associated piping and concrete were demolished and removed as scrap in September, 1998. On September 11, 1998, ESH Health 
Physics personnel surveyed the piping that was inaccessible under the concrete (See Figure 9). Pipes involved were those pipes that ran from under the concrete to the north pit drain and east pit drain leading to the water treatment settling basin. No contamination was detected. The north drain line was removed to three feet outside of the foundation of the building. The east drain line was removed to the foundation of building 593 (see Figure 1).

10. Direct and Smear Results: Health Physics results are listed in Appendix C.

\section{SUMMARY}

The Waste Ion Exchange Facility was free released for demolition on July 30, 1998. No surprises or unknowns were noted. The building and associated piping were demolished and removed in September, 1998. The north drain line was removed to three feet outside of the foundation of the building. The east drain line was removed to the foundation of Building 593. The piping located in the north pit drain and east pit drain (which were located under the concrete) were free released. The catch basin, which was located on the south side of the building and also connected to equalization tanks in building 592, was released for unrestricted use and was left intact.

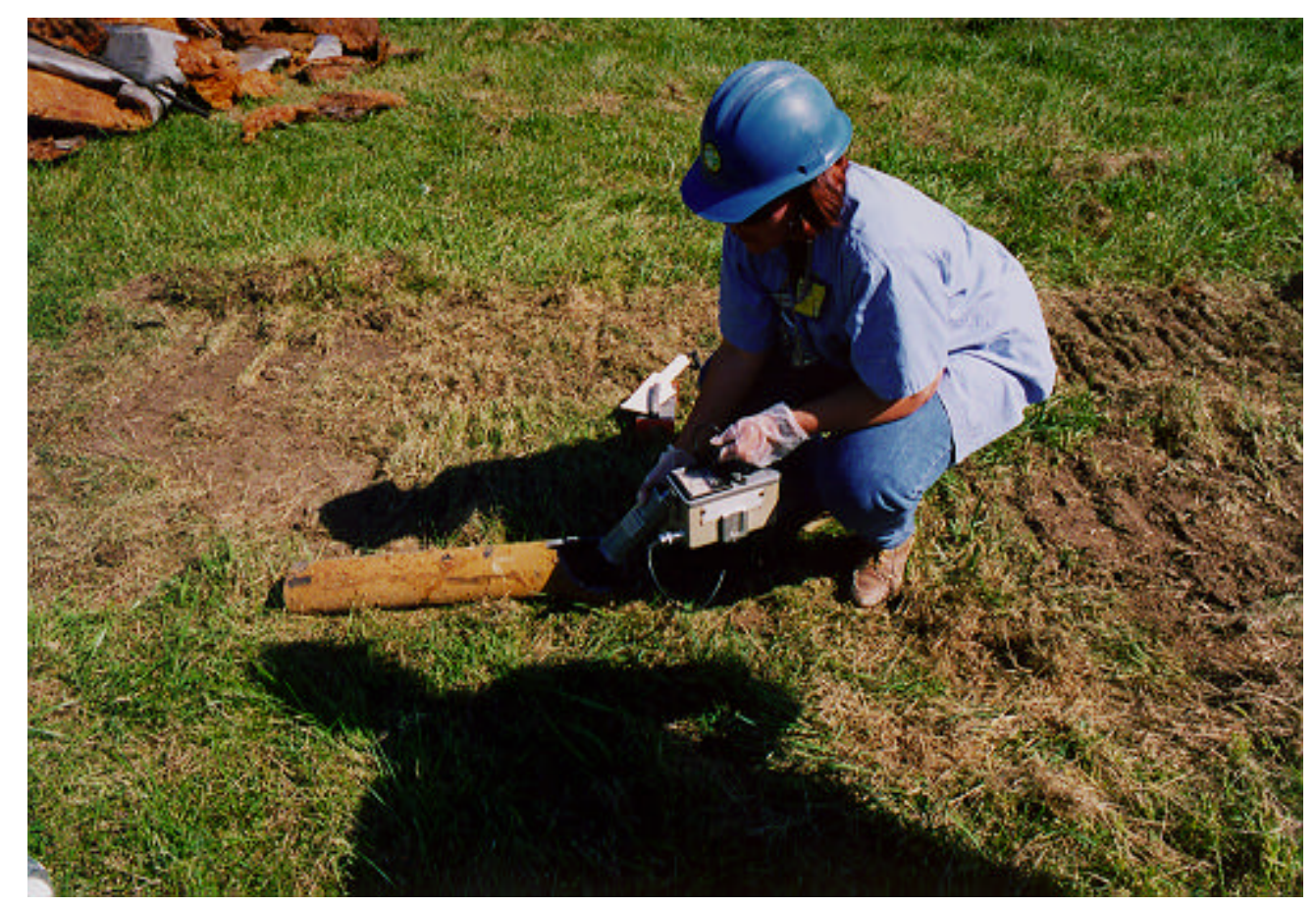

FIGURE 9 Health Physics Survey of Piping from beneath Building 594 Concrete Pad 


\section{REFERENCES}

1. USNRC Regulatory Guide 1.86, "Termination of Operating Licenses for Nuclear Reactors" 1974.

2. DOE Order 5400.5, "Radiation Protection of the Public and the Environment" (1990).

3. Draft DOE Rule 10 CFR 834, "Radiation Protection of the Public" (1995).

4. "Building 579 Waste Ion Exchange Facility Characterization Report" C.M. Sholeen, D.C. Geraghty, Argonne National Laboratory, Argonne, Illinois, ANL/ESH-HP-97/01, March, 1997.

5. "Health and Safety Plan for the Decontamination and Decommissioning of Building 594 Waste Ion Exchange Facility", R. Hysong, E. Wiese, Argonne National Laboratory, Argonne, Illinois, May, 1998. 
APPENDIX A:

INSTRUMENT CALIBRATION \& OPERATIONAL CHECK RECORDS 
A-2 
Certificate \#018-A1

rev. 1.0, June 1993

\section{INSTRUMTHT MAINTENANCE/CALIBRATION CERTIFICATE}

Set\#: 17 Procedure\#: 018 Configuration: Scintillator Type: $\frac{1}{-x-2} \mathrm{~mm} \mathrm{NaI}$

Unit\#:44/7 Mfr/Model: Eberline PRM-5-3 S/N:2403

Unit\#:2682 Mfr/Model: Eberline PG-2

$\mathrm{S} / \mathrm{N}$ :

Pulse Generator, Eberline MPElectrostatic Kilovoltmeter:

Source (s): $\mathrm{Pu}-239, \mathrm{~S} / \mathrm{N} 7552$

Am-241, S/N 7551

$\mathrm{U}-235, \mathrm{~S} / \mathrm{N} 22 \mathrm{~B} 6102$

$\mathrm{s} / \mathrm{N} 200$

SRavisom

$s / N / 53>4$

, Activity $4150000 \mathrm{dpm}$

- Activity $6028000 \mathrm{dpm}$

, Activity $1.06 \mathrm{~g}$ foil

\section{I) MAINTEATANCE/PRECALIBRATION:}

Batteries: I Cabling:___ Mechanical/Cleanliness:

Threshold: // $\mathrm{mV}$ (fixed at 5 to $10 \mathrm{mV}$ )

Window: II/9mV $=\frac{25}{2}$ (ref.: $25 \%$ of Threshold mV)

Audible Function check: COR

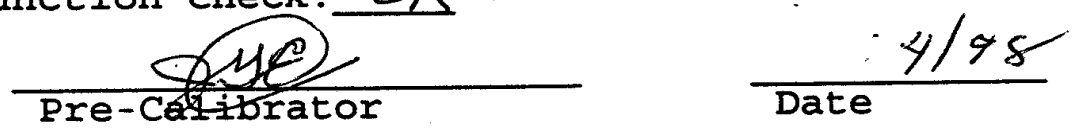

II)

TRMARY CAIIBRATION:

\begin{tabular}{|c|c|c|c|c|}
\hline $\begin{array}{c}\text { Range } \\
\text { (cpm) } \\
52\end{array}$ & $\begin{array}{l}\text { Pulser } \\
\text { Rate } \\
\text { (cpm) } \\
\not 4 D C\end{array}$ & $\begin{array}{l}\text { As } \\
\text { Found } \\
\text { (cpm) } \\
380\end{array}$ & $\begin{array}{l}\text { As } \\
\text { Left } \\
\text { (cpm) }\end{array}$ & $\begin{array}{l}\text { \% Diff. } \\
\text { Pulser vs } \\
\text { As Left }\end{array}$ \\
\hline 83 & 41 & $98: 5$ & & \\
\hline$R 4$ & $40 K$ & $4 k$ & & \\
\hline R5 & 400K & 3256 & & \\
\hline
\end{tabular}

With PHA in, adjust HV to maximize detector response to isotope of interest:

\begin{tabular}{cccc} 
Mode & \multicolumn{2}{c}{ Response } & Efficiency \\
Isotope & As Found As Left & (If Applicable) \\
(cpm) & (cpm) & ( $q$ (c)
\end{tabular}

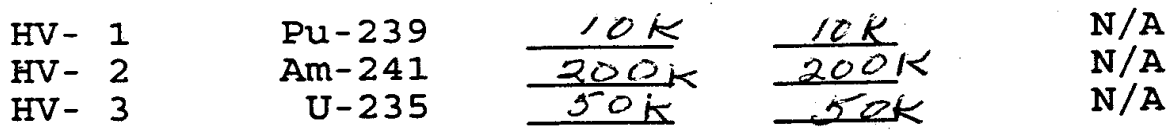

Mode of Operation: EV- 1 , Gross
Ambient Bkgd in chosen Oper. Mode: $/ K$ cpm (ref.: > $300 \mathrm{cpm}$ )

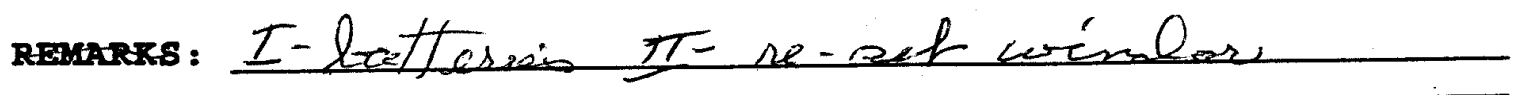

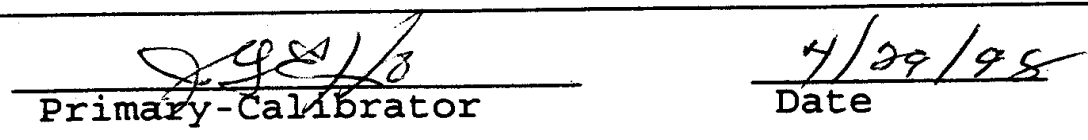


rev. 1.2, March 1997

\section{INSTRUMENT MAINTENANCE/CALIBRATION CERTIFICATE}

set\#:505 Procedure\#: 015 Configuration: surface contam Type: $\frac{x}{x}$ Dual Scintiliator (dpm units) Unit\#: प965 Mfr/Model: NE Technology Electra Unit\#:6909 Mfr/Model: NE Technology DP6 Pulse Generator, Eberline MP- $2, s / N+75$

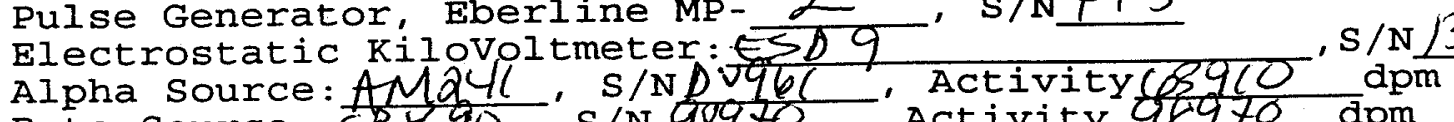
Beta source: SeY90, S/N $98970, '$ Activity 98970 dpm

$\mathrm{S} / \mathrm{N}:$ $S / N: \longdiv { 5 7 3 }$

\section{I) MAINTENANCE/PRECALIBRATION :}

Window : Cabling: Mechaniçal/Cleanliness: Battery Voltage (Parameter \# 0): 4,3 (ref: > 4) Threshold: 30 (verify $25 \mathrm{mv}$ with the Minipulser) Count Rate Check @10 k cpm: HV Calib.: 1 (compare Parameter \#3 w/ the Electrostatic)

High Voltage Adjustment: Temporarily raise ULD. Using Sr-90 source, observe count rate in beta channel as a function of HV. Adjust HV to $50 \mathrm{~V}$ above the knee of the plateau. HV $=870$, and INHIBIT:

Now bring down the ULD so that count rate in alpha channel is approx. 0.1\% or less of count rate in beta channel.

Beta c... $28.7 \mathrm{~K}$ Alpha cpm: 2 (e.g., L.l of beta)

ULD (Parameter \#6) $2.0 \mathrm{~V}(\overline{\text { ref: } 2.00 \mathrm{~V})}$, then INHIBIT:

Parameter settings:

As the Electra "supervisor" (i.e., the internal switch SI2 to $O N)$, set the remaining parameters as follows:

Parameter \#I (Alarm Level): OFF, then INHIBIT:

Parameter \#4 (Overload Current): $10 \mu \mathrm{A}$, then INHIBIT:

parameter \#5 (Deadtime): $3 \mu \mathrm{sec}$, then INHIBIT:

Parameter \#8 (Units): cpm

Parameter \#A (inhibit bkgd subt): set to ON

Parameter \#b (inhibit integrate): set to OFF

parameter \#C (rate mode): set to Auto

Parameter \#E (pulse mode): set to dUAL

Parameter \#F (ohms): set to 566

II) PRIMARY CAIIBRATION: $9 \mathrm{~K}$ cpm;, 201 of efficiency (alpha) Alpha Mode Bkgd: 4 cpm (ref.: $<7 \mathrm{cpm})$

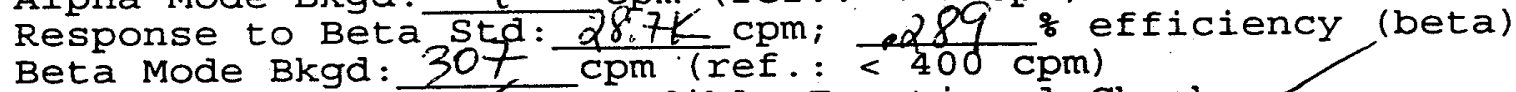

Integrate Check: $\longleftarrow$ Audible Functional Check:

Parameter \#8 (Units): change from cpm to dpm

Parameter \#9 (Efficiencies): enter efficiencies from above Now set switch Si-2 back to OFF (user), and leave switch $\mathrm{SI}-3$ set to ON (hide).

REMARKS :

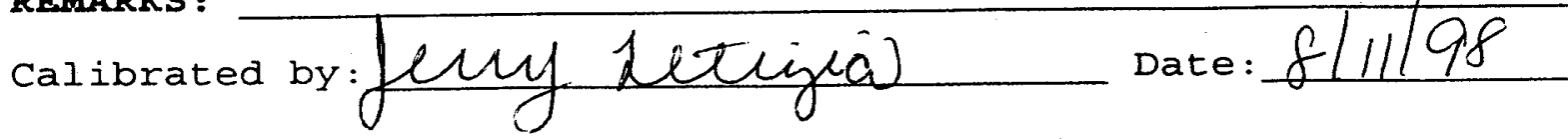


Certificate \#018-A1

rev. 1.0, June 1993

\section{INSTROMOENT MAINTENANCE/CALIBRATION CERTIFICATE}

Set\#: 96 Procedure\#: 018 Configuration: Scintillator Type: $\frac{96}{x_{-}} 2 \mathrm{~mm} \mathrm{NaI}$
Unit $: 4524$
Unit\#: $: 2973$
Mfr/Model:
Mfr/Model:
Eberline PRK-5-3
$S / N: 29 / 2$
Eberline PG-2
$\mathrm{S} / \mathrm{N}$ :

Pulse Generator, Eberline MPElectrostatic KiloVoltmeter: Source (s): Pu-239., S/N 7552 $\mathrm{Am}-241, \mathrm{~S} / \mathrm{N} 7551$ $\mathrm{U}-235$

$\mathrm{s} / \mathrm{N} 200$

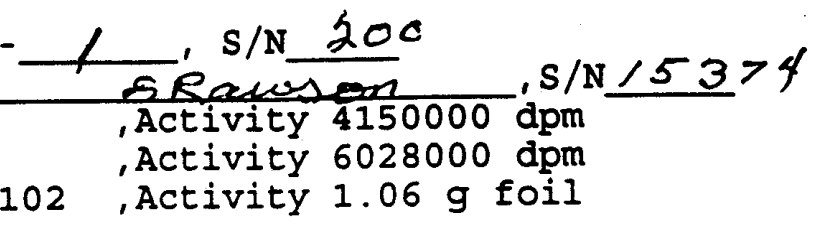

\section{I) MAINTEKNANCE/PRECAIIBRATION :}

Batteries: $\frac{}{2}$ Cabling: 111 Mechanical/Cleanliness: IIE

Threshold: $8 \mathrm{mV}$ (fixed at 5 to $10 \mathrm{mV}$ )

Window: $\frac{10 \mathrm{mV}}{2}=25$ (ref.: $25 \%$ of Threshold $\mathrm{mV}$ ) Audible Function check: $\hat{A k}$
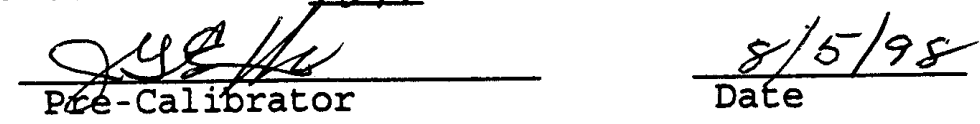

\section{II) EXIMARY CAIIBRATION:}

\begin{tabular}{|c|c|c|c|c|}
\hline $\begin{array}{c}\text { Range } \\
\text { (cpm) } \\
52\end{array}$ & $\begin{array}{l}\text { Pulser } \\
\text { Rate } \\
\text { (cpm) } \\
4 \text { OO }\end{array}$ & $\begin{array}{l}\text { As } \\
\text { Found } \\
\text { (cpm) } \\
\text { 1\%o }\end{array}$ & $\begin{array}{l}\text { As } \\
\text { Left } \\
\text { (cpm) } \\
400\end{array}$ & $\begin{array}{l}\text { o Diff. } \\
\text { Pulser vs } \\
\text { As Left }\end{array}$ \\
\hline & $4 \mathrm{~K}$ & $42 \mathrm{~K}$ & $3.9 \mathrm{~K}$ & \\
\hline 24 & $40 \mathrm{~K}$ & 4015 & $42 k$ & \\
\hline R5 & 400K & $360 k$ & $400 \mathrm{~K}$ & \\
\hline
\end{tabular}

With PHA in, adjust HV to maximize detector response to isotope of interest:

$\begin{array}{ccc}\text { Response } & \text { Efficiency } \\ \text { Mode } & \text { Isotope As Found As Left } & \text { (If Applicable) } \\ (\mathrm{cpm}) & (\mathrm{cpm}) & \left(\frac{q}{6}\right)\end{array}$

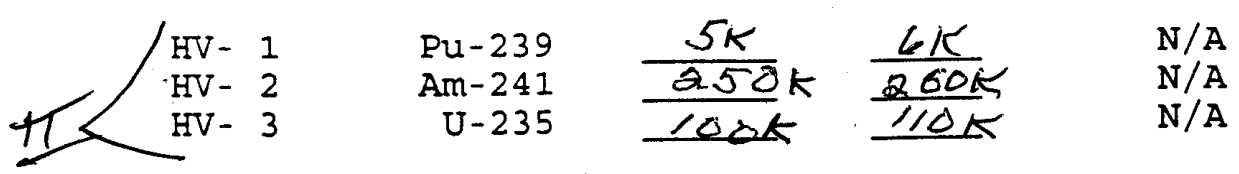

Mode of Operation: IV- 1 , Gros8

Ambient Bkgd in chosen Oper. Mode $(250 \mathrm{cpm}$ (ref.: >300 cpm)

ramarks: I-latterias $\pi$-re-cal

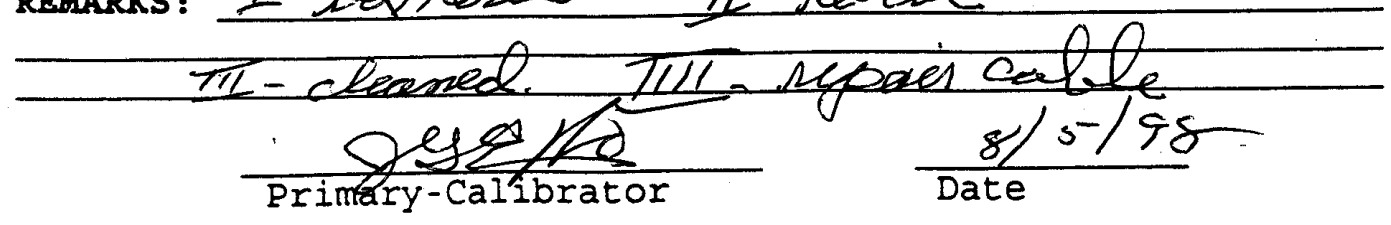


Certificate \#015-D2

rev. 1.2, March 1997

\section{INSTRUMENT MAINTENANCE/CALIBRATION CERTIFICATE}

Set\#:1053 Procedure\#: 015 Configuration: surface contam Type: $\mathbf{x}$ Dual Scintiliator (dpm units) Unit\#: 5493 Mfr/Model: NE Technology Elegtra Unit\#: 6817 Mfr/Model: NE Technology DP6A

$\mathrm{S} / \mathrm{N}: 5 / 3$

$S / N: 605$

Pulse Generator, Eberline MP- 2 , s/N 775

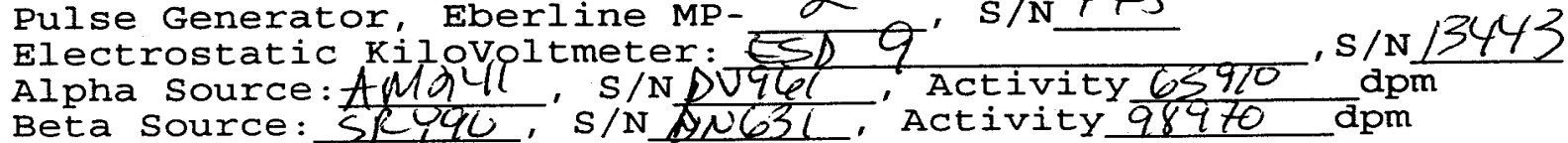
Beta Source: SRYQL', S/N AN631.'Activity 98970 dpm

\section{I) MAINTENANCE/PRECALIBRATION :}

Window: 1 Cabling: Mechanical/Cleanliness :

Battery Voltage (Parameter \# 0): 4,5 (ref: > 4)

Threshold: 30 (verify $25 \mathrm{mv}$ with the Minipulser)

Count Rate Check @10k cpm: OR

HV Calib.: L (compare Parameter \#3 w/ the Electrostatic)

High Voltage Adjustment:

Temporarily raise ULD. Using $\mathrm{Sr}-90$ source, observe count rate in beta channel as a function of HV. Adjust HV to $50 \mathrm{~V}$ above the knee of the plateau. HV $=820$, and INHIBIT: -

Now bring down the ULD so that count rate in alpha channel is approx. 0.1 or less of count rate in beta channel.

Beta cpm: $28 \mathrm{~K}$ Alpha cpm: 6 (e.g., $\leq .1 \%$ of beta)

ULD (Parameter \#6): $2.0 \mathrm{~V}$ (ref: $2.00 \mathrm{v})$, then INHIBIT:

Parameter settings :

As the Electra "supervisor" (i.e., the internal switch S1-

2 to $O N)$, set the remaining parameters as follows:

Parameter \#1 (Alarm Level): OFF, then INHIBIT:

Parameter \#4 (Overload Current): $10 \mu \mathrm{A}$, then INHIBIT:

Parameter \#5 (Deadtime): $3 \mu$ sec, then INHIBIT:

Parameter \#8 (Units): cpm

Parameter \#A (inhibit bkgd subt): set to oN

parameter \#b (inhibit integrate): set to OFF

parameter \#C (rate mode): set to Auto

Parameter \#E (pulse mode): set to dUAL

Parameter \#F (ohms): set to 566

II) PRIMARY CALIBRATION: $1 K$ cpm; $204 \%$ efficiency (alpha) Alpha Mode Bkgd: 4 cpm (xef.: $\frac{4 \mathrm{cpm})}{<7}$

Response to Beta sta: $28 \mathrm{~K} \mathrm{cpm} ; .282^{\circ}$ efficiency (beta)

Beta Mode Bkgd: $255 \mathrm{cpm}$ (ref.: <400 cpm)

Integrate Check:_ Audible Functional Check:

Parameter \#8 (Units): change from cpm to dpm

Parameter \#9 (Efficiencies): enter efficiencies from above Now set switch S1-2 back to OFF (user), and leave switch SI-3 set to ON (hide).

REMARKS :

calibrated by:fluf kitaina Date: 
Certificate \#006, Page 1 rev. 0.3, Dec. 1995

\section{INSTRUMEANT MAINTEANANCE/CALIBRATION CERTIFICATE}

set\# : 1753 Description:

Unit. : 14

Unit\# : 西早76s

Unit\# :

Procedure\# : 006 DABRAs wth Counter 1

Configuration:

Assay system DABRAS with Counter- 1 _ $x_{-}$

Mfr/Model: ANL-B DABRAS Mfr/Model: 2

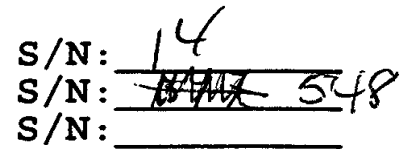

Pulse Generator, Eberline MP-2, s/N 775

voltmeter: Fluke 83 is 46600185

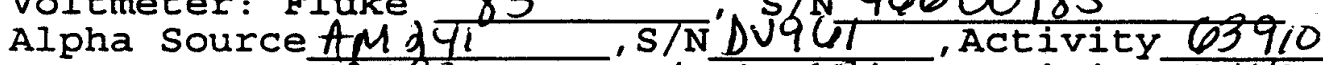

Beta source SeY 90 , s/N sNG31, Activity 109400

\section{I) MAINTEANANCE/PRECALIBRATION :}

Detector Window (s) : CabJe(s): $/$ other Mechanical: Keyboard \& Monitor Check: Audible Function Check:

Note: If full precalibration is required, go to page 2 .

\section{II) PRIMARY CATIBRATION:}

DABRAS Software Date (on splash screen): $6 / 28 / 97$ Counter 1 utilizes Mz200 S/N: 7654

Count- 2 utilizes MZ200 S/N:

Address select Thumbwheel Setting (ref : 7): 7

DABRAS-Supplied Voltages:

Counter 1 Counter 2

+15 Vdc Power Supply

-15 Vdc Power Supply

HV Control (ref: 4.5 Vac)

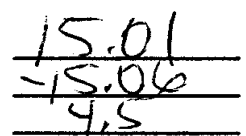

Responses to MP-2 Iine Driver Output: With MP unit set for $80 \mathrm{k} \mathrm{cpm}$, observe channel responses. Alpha Channel (ref: $40 \mathrm{k} \mathrm{cpm} \pm 1 \%$ ) Beta Channel (ref: $40 \mathrm{k} \mathrm{cpm} \pm 1 \%$ )

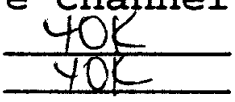

Determination of Instrument Parameters:

With an empty tray, initiate the 100-minute background count: Alpha Background (ref: $\leq 4 \mathrm{cpm}$ )

Beta Background (ref: $\leq 350 \mathrm{cpm}$ )

Measured efficiencies after the 10 -minute standard counts:

Alpha Efficiency (ref: $26 \pm 3 \%$ )

Beta Efficiency (ref: $49 \pm 3 \%$ )

"Convince-Yourself" Check ( $\alpha$ std.)

of Standard dpm values: ( $B$ std.)

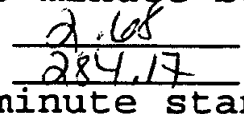

REMARRS :

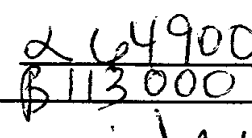

Calibrated By: jewa

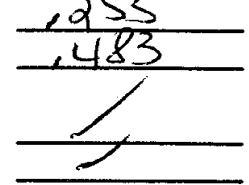

Calibrated By:

$\int \frac{(\operatorname{ta}(\dot{\mu q})}{\text { Re-calibration Due }}$

Date: 
Certificate \#006, Page 1 rev. 0.3, Dec. 1995

\section{INSTRULGANT MAINTEANANCE/CALIBRATION CERTIFICATE}

Set\#:1714 Procedure\# : 006 Configuration: Assay system Description: DABRAs with Counter- $1-x_{-} x$

Unit\#: 16 Mfr/Model: ANT-E DABRAS

Unit\#: 9991 Mfr/Model: EGeg Berthold Mz200

Unit: $: 174$ Mfr/Model: 11

Pulse Generator, Eberline MP-2, s/N; 775

voltmeter: Fluke 83 is

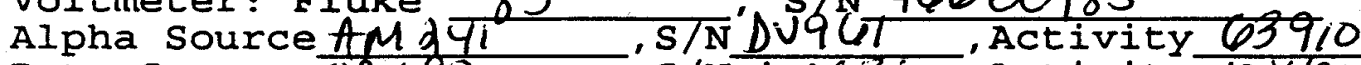

Beta source SRY 90 , s/N 10631 , Activity 109400

\section{I) MAINTEINANCE/PRECAIIBRATION :}

Detector window(s): $/$ Cabje(s): Other Mechanical: Keyboard \& Monitor Check: Audible Function Check:

Note: If full precalibration is required, go to page 2 .

\section{II) PRIMARY CALIBRATION:}

DABRAS Software Date ion splash screen): $6 / 28 / 97$

Counter 1 utilizes Mz200 S/N:9991

Count- -2 utilizes MZ200 S/N: 6177

Address select Thumbwheel setting (ref: 7):7

DABRAS-Supplied Voltages:

+15 Vdc Power Supply

-15 Vdc Power Supply

HV Control (ref: 4.5 Vac)

Counter 1

Counter 2

Responses to MP-2 Iine Driver Output:

With MP unit set for $80 \mathrm{k} \mathrm{cpm}$, observe channel responses.

Alpha Channel (ref: $40 \mathrm{k} \mathrm{cpm} \pm 1 \%$ )

Beta Channel (ref: $40 \mathrm{k} \mathrm{cpm} \pm 1 \%$ )

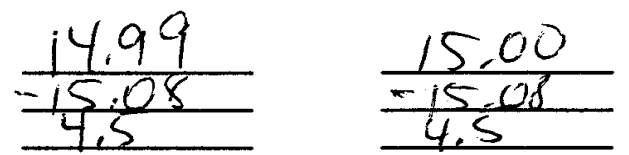

Determination of Instrument Parameters:

With an empty tray, initiate the 100-minute background count: Alpha Background (ref: $\leq 4 \mathrm{cpm}$ )

Beta Background (ref: $\leq 350 \mathrm{cpm}$ )

Measured efficiencies after the

Alpha Efficiency (ref: $26 \pm 3 \%$ )

Beta Efficiency (ref: $49 \pm 3 \%$ )

"Convince-Yourself" Check ( $\alpha$ std.)

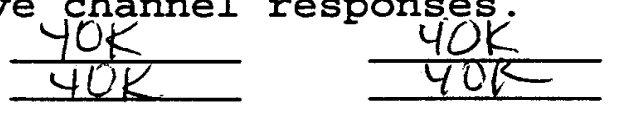

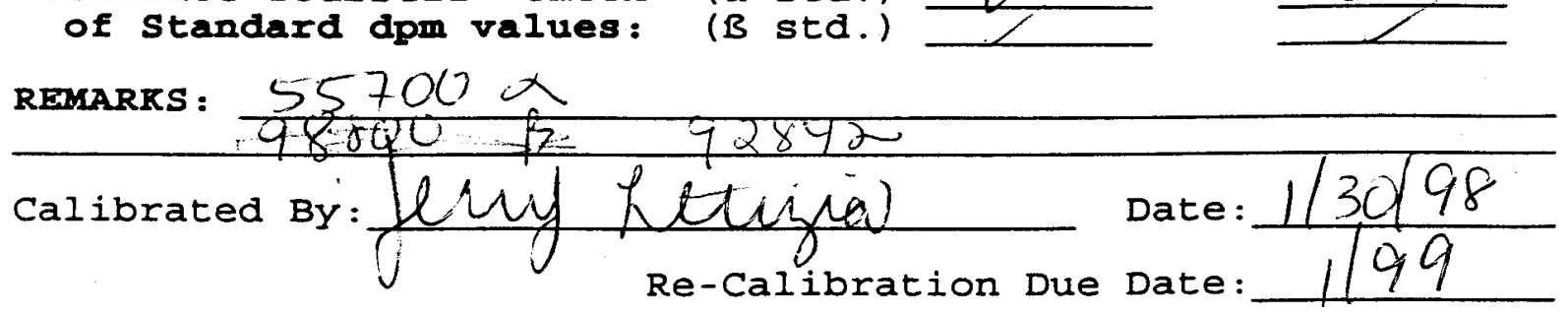




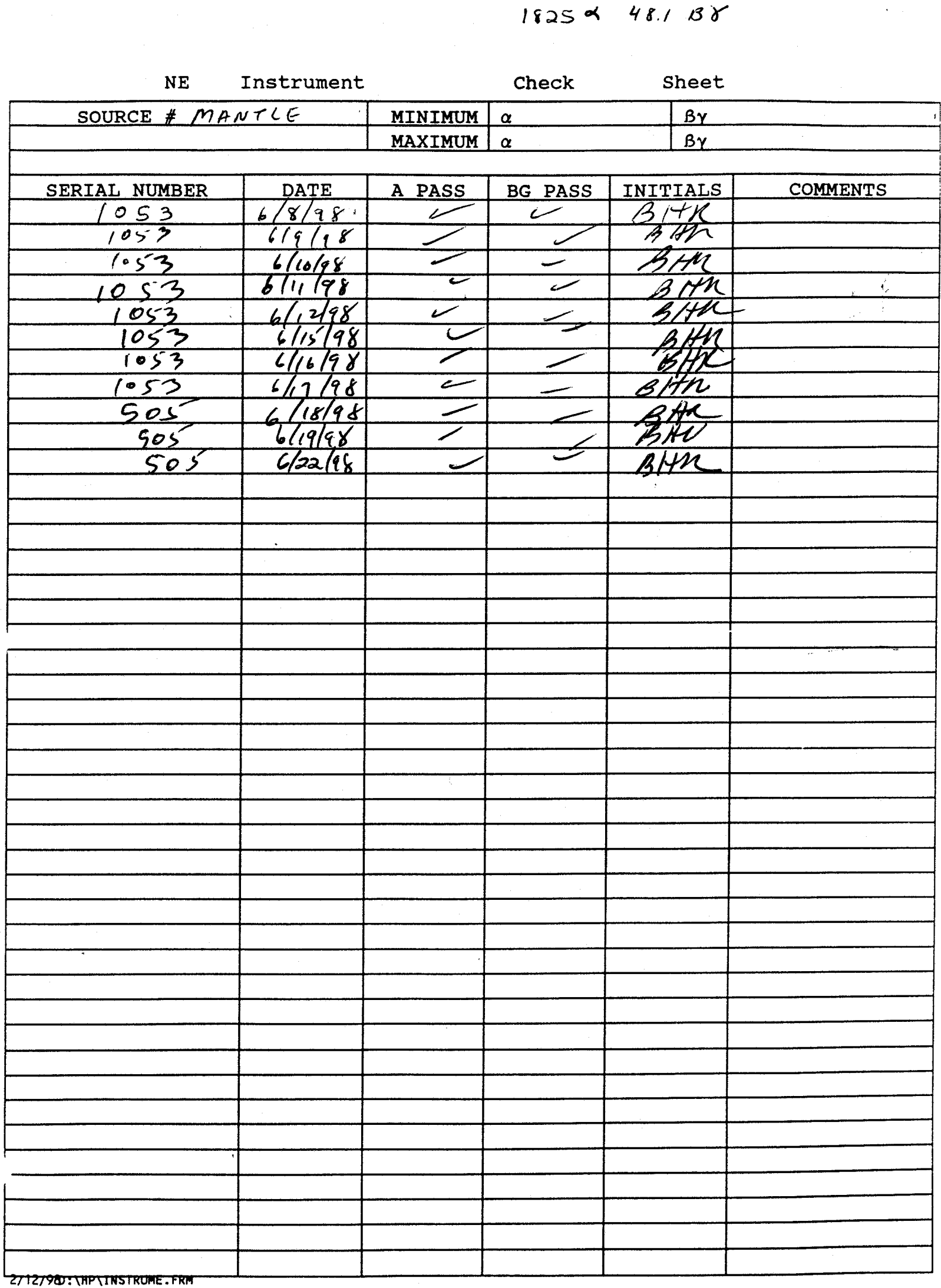




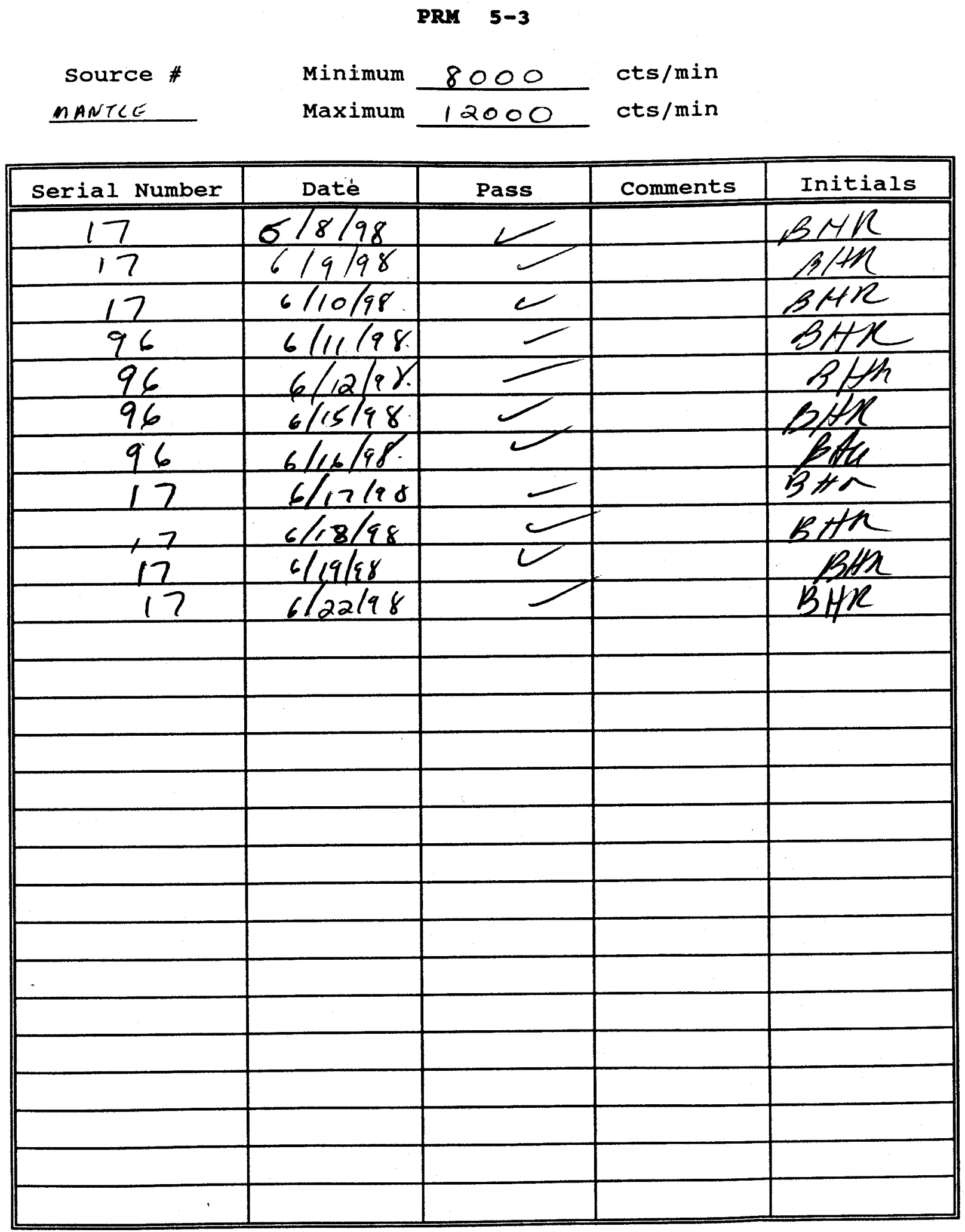

5/18/98 D: \HP\FORMS. 306 
APPENDIX B:

UNRESTRICTED RELEASE DOCUMENTS 
B-2 
$\begin{array}{lll}\text { To: } & \text { T. Yule } & \text { TD } \\ & \text { E. Wiese } & \text { TD } \\ \text { From: } & \text { C. M. Sholeen } & \end{array}$

Subject: Building 594 Tritium smear survey after D\&D

Four smears were taken from areas in Building 594 that were deemed to be most likely to contain residual tritium. The smears were obtained by wiping an area $\geq 100 \mathrm{~cm}^{2}$ with a styrofoam type smear media. Each smear was placed in a scintillation vial and dissolved in Liquid Gold scintillation cocktail. A control vial and each vial with a dissolved smear was counted for 2 minutes on a Packard Tri-Carb 1600 TR Liquid Scintillation Analyzer. The table below contains a list of the four smears and the analysis results.

\begin{tabular}{lcc}
\hline Location & $\begin{array}{c}{ }^{3} \mathrm{H} \text { Activity } \\
\text { gross }\end{array}$ & net \\
\hline \hline Control & 40.82 & 0.00 \\
Drain to manhole & 72.83 & 32.01 \\
Drain behind tank & 38.70 & NCD \\
Trench & 70.05 & 29.23 \\
Drain in retention area & 89.42 & 48.60 \\
\hline \multicolumn{2}{c}{ NCD = No Contamination Detected }
\end{tabular}

As seen in the last column, low levels of tritium were detected on three of the four smears. However, these values are less than $10 \%$ of the unrestricted release criteria for beta-gamma emitters of $1,000 \mathrm{dpm} / 100 \mathrm{~cm}^{2}$. At the present time tritium is included as one of these beta-gamma emitters. There is a possibility that a higher limit will be set for tritium in the future.

CC:

M. J. Robinet 
ARGONNE

NATIONAL

To: E. Wiese TD

From: $\quad$ C. M. Sholeen CW/S ESH-HP

Subject: Health Physics survey of Building 594 after D\&D Revision to the memo dated July 17, 1998.

The walls, windows, floors and doors of building 594 were surveyed direct for both $\alpha$ and $\beta \gamma$ contamination. None was detected. Smears of the area had no $\alpha$ or $\beta \gamma$ contamination. other parts of the building that were surveyed and found to be free from loose and fixed contamination are the HEPA filter and housing, the exhaust pipe that comes down from the ceiling, the outside vent pipe and the pipe going into the floor down to 6 inches below the surface. The ceiling and light fixtures were spot checked and found to be free from loose and fixed contamination. Tritium smears were taken of the trench and 3 drain pipes; low levels of tritium were found. However, all smears were below the tritium release criteria. The building and fixtures are released for unrestricted use.

As found during the characterization, the manhole had direct $Y$ activity above the ambient background. The manhole sample taken during the characterization appeared to contain only naturally occurring radionuclides. The activity levels are below the unrestricted release criteria. Therefore, the manhole is released for unrestricted use.

Items and the resin that were removed from the building were surveyed to determine the appropriate disposal. The results of these surveys and the building surveys were attached to the memo dated July 17, 1998.

CC:

$$
\text { M. J. Robinet }
$$


APPENDIX C:

DIRECT \& SMEAR SURVEY RESULTS 
C-2 
TABLE C.1 Building 594 Health Physics Survey Results

\begin{tabular}{|c|c|c|c|c|c|}
\hline \multirow{2}{*}{$\begin{array}{r}\text { Date } \\
6 / 8 / 98\end{array}$} & \multirow{2}{*}{$\begin{array}{r}\text { Item or Area } \\
\text { Locker \#2 }\end{array}$} & \multicolumn{2}{|c|}{$\alpha$ Direct $\beta \gamma$} & \multicolumn{2}{|c|}{$\alpha$ Smear } \\
\hline & & $\mathrm{NCD}^{\mathrm{a}}$ & NCD & NCD & NCD \\
\hline $6 / 8 / 98$ & Locker \#1 & NCD & NCD & $\mathrm{NCD}$ & NCD \\
\hline 6/8/98 & Locker \#5 & NCD & NCD & NCD & NCD \\
\hline 6/8/98 & Shelf \#1 & NCD & NCD & NCD & NCD \\
\hline 6/8/98 & Shelf \#2 & NCD & NCD & NCD & $\mathrm{NCD}$ \\
\hline 6/8/98 & Shelf \#3 & NCD & NCD & NCD & NCD \\
\hline 6/8/98 & Bricks \#1-5 & NCD & NCD & NCD & NCD \\
\hline 6/8/98 & Wood $\sim 2 " \times 12^{\prime \prime} \times 8^{\prime}$ & NCD & NCD & NCD & NCD \\
\hline $6 / 8 / 98$ & Motor & NCD & NCD & NCD & NCD \\
\hline 6/8/98 & Bricks \#6-8 & NCD & NCD & NCD & NCD \\
\hline 6/8/98 & Electrical panel (face plate) & NCD & NCD & NCD & NCD \\
\hline 6/8/98 & 2-motors & NCD & NCD & NCD & NCD \\
\hline $6 / 8 / 98$ & 1-motor (small) & NCD & NCD & NCD & NCD \\
\hline 6/8/98 & Pipe PVC & NCD & NCD & NCD & NCD \\
\hline $6 / 8 / 98$ & Copper pipe & NCD & NCD & $\mathrm{NCD}$ & NCD \\
\hline $6 / 8 / 98$ & Couplings - 6 & NCD & NCD & NCD & NCD \\
\hline 6/8/98 & Misc. fittings & NCD & NCD & NCD & NCD \\
\hline 6/8/98 & Shelf \#4 & NCD & NCD & NCD & NCD \\
\hline 6/8/98 & Pipe and site glass & NCD & NCD & $\mathrm{NCD}$ & NCD \\
\hline $6 / 8 / 98$ & Floors & - & - & NCD & NCD \\
\hline 6/9/98 & Conduit (2) & NCD & NCD & $\mathrm{NCD}$ & NCD \\
\hline 6/9/98 & Round tank & NCD & NCD & $\mathrm{NCD}$ & NCD \\
\hline 6/9/98 & Rectangular SS tank & NCD & NCD & $\mathrm{NCD}$ & NCD \\
\hline 6/9/98 & 2 mixers & NCD & NCD & NCD & $\mathrm{NCD}$ \\
\hline 6/9/98 & South wall \#1 (lower) & NCD & NCD & $\mathrm{NCD}$ & NCD \\
\hline 6/9/98 & South wall \#2 (lower) & NCD & NCD & $\mathrm{NCD}$ & NCD \\
\hline 6/9/98 & South wall \#3 (lower) & NCD & NCD & $\mathrm{NCD}$ & NCD \\
\hline 6/9/98 & East wall \#1-4 (lower) & NCD & NCD & $\mathrm{NCD}$ & NCD \\
\hline 6/9/98 & Bricks 1-12 & NCD & NCD & NCD & NCD \\
\hline 6/9/98 & West wall (lower) \#1 and 2 & NCD & NCD & NCD & NCD \\
\hline 6/9/98 & PVC pipes & $\mathrm{NCD}$ & NCD & $\mathrm{NCD}$ & $\mathrm{NCD}$ \\
\hline 6/9/98 & 3 motors & NCD & NCD & NCD & NCD \\
\hline 6/9/98 & 2 site glasses & NCD & NCD & $\mathrm{NCD}$ & NCD \\
\hline 6/9/98 & Valves & NCD & NCD & $\mathrm{NCD}$ & NCD \\
\hline $6 / 9 / 98$ & Floors & - & - & NCD & NCD \\
\hline $6 / 10 / 98$ & North wall \#1 & NCD & NCD & $\mathrm{NCD}$ & NCD \\
\hline $6 / 10 / 98$ & Railings into retention tank area & NCD & NCD & $\mathrm{NCD}$ & NCD \\
\hline 6/10/98 & Lids \#1 and 2 from tanks & NCD & NCD & $\mathrm{NCD}$ & NCD \\
\hline $6 / 10 / 98$ & Wire cord & NCD & NCD & $\mathrm{NCD}$ & NCD \\
\hline $6 / 10 / 98$ & Pipes from trench & NCD & NCD & $\mathrm{NCD}$ & NCD \\
\hline $6 / 10 / 98$ & Inside tanks \#1 (right) & - & - & $\mathrm{NCD}$ & $\mathrm{NCD}$ \\
\hline $6 / 10 / 98$ & Inside tank \#2 (left) & - & - & NCD & 180 \\
\hline $6 / 10 / 98$ & Floors & - & - & $\mathrm{NCD}$ & NCD \\
\hline
\end{tabular}


TABLE C.1 (Cont.)

\begin{tabular}{|c|c|c|c|c|c|}
\hline \multirow{2}{*}{$\begin{array}{l}\text { Date } \\
6 / 11 / 98\end{array}$} & \multirow{2}{*}{$\begin{array}{r}\text { Item or Area } \\
\text { West overhead door }\end{array}$} & \multicolumn{2}{|c|}{$\alpha$ Direct $\beta \gamma$} & \multicolumn{2}{|c|}{$\alpha$ Smear } \\
\hline & & $\mathrm{NCD}$ & NCD & NCD & NCD \\
\hline $6 / 11 / 98$ & Mixers & $\mathrm{NCD}$ & NCD & NCD & NCD \\
\hline $6 / 11 / 98$ & Overhead pipes & NCD & NCD & NCD & NCD \\
\hline 6/11/98 & Filter and filter media & $\mathrm{NCD}$ & $\mathrm{NCD}$ & NCD & NCD \\
\hline $6 / 11 / 98$ & Conduit & NCD & NCD & NCD & NCD \\
\hline $6 / 11 / 98$ & Copper pipes & NCD & NCD & NCD & NCD \\
\hline $6 / 11 / 98$ & West wall near electrical panel & NCD & NCD & NCD & NCD \\
\hline $6 / 11 / 98$ & Floors & - & - & NCD & NCD \\
\hline $6 / 12 / 98$ & Resin stirrers & NCD & NCD & NCD & NCD \\
\hline $6 / 15 / 98$ & Pipe from Tank L & NCD & NCD & NCD & NCD \\
\hline \multicolumn{6}{|c|}{ Drums Containing Resin } \\
\hline $6 / 12 / 98$ & Resin drum \#1-R & $\mathrm{NA}^{\mathrm{b}}$ & $4,000^{\mathrm{c}}$ & NCD & NCD \\
\hline 6/12/98 & Resin drum \#2-R & NA & 13,000 & NCD & NCD \\
\hline 6/12/98 & Resin drum \#3-R & NA & 13,000 & NCD & NCD \\
\hline $6 / 12 / 98$ & Resin drum \#4-R & NA & 12,000 & NCD & NCD \\
\hline $6 / 12 / 98$ & Resin drum \#5-R & NA & 3,000 & NCD & NCD \\
\hline 6/15/98 & Resin drum \#1-L & NA & 200 & NCD & NCD \\
\hline 6/15/98 & Resin drum \#2-L & NA & 200 & NCD & NCD \\
\hline $6 / 15 / 98$ & Resin drum \#3-L & NA & 300 & NCD & NCD \\
\hline $6 / 15 / 98$ & Resin drum \#6-L & NA & NCD & NCD & NCD \\
\hline $6 / 15 / 98$ & Resin drum \#7-R & NA & 1,000 & NCD & NCD \\
\hline $6 / 16 / 98$ & Pipe going into floor & NCD & NCD & NCD & $\mathrm{NCD}$ \\
\hline $6 / 16 / 98$ & Pipes from left column & $\mathrm{NCD}$ & NCD & NCD & NCD \\
\hline $6 / 17 / 98$ & Retention tank & NCD & NCD & NCD & NCD \\
\hline 6/17/98 & Site glass from left tank & NCD & NCD & NCD & NCD \\
\hline 6/17/98 & Trench tops & NCD & NCD & NCD & NCD \\
\hline 6/17/98 & Trench & NCD & NCD & NCD & NCD \\
\hline 6/17/98 & Socks & $\mathrm{NCD}$ & NCD & NCD & NCD \\
\hline 6/17/98 & Drain cover in retention area & NCD & NCD & NCD & NCD \\
\hline 6/17/98 & Pipe from retention area & $\mathrm{NCD}$ & NCD & NCD & NCD \\
\hline 6/17/98 & Masonite ring & NCD & NCD & NCD & NCD \\
\hline 6/17/98 & Signs & NCD & NCD & NCD & NCD \\
\hline 6/17/98 & Retention tank walls, drain, floor & $\mathrm{NCD}$ & NCD & NCD & NCD \\
\hline 6/17/98 & Ladder & NCD & NCD & NCD & NCD \\
\hline $6 / 17 / 98$ & Pump from retention tank & NCD & NCD & NCD & NCD \\
\hline 6/18/98 & Motor & NCD & NCD & NCD & NCD \\
\hline $6 / 18 / 98$ & Filters & NCD & NCD & NCD & NCD \\
\hline
\end{tabular}


TABLE C.1 (Cont.)

\begin{tabular}{|c|c|c|c|c|c|}
\hline \multirow{2}{*}{$\frac{\text { Date }}{6 / 19 / 98}$} & \multirow{2}{*}{$\begin{array}{l}\text { Item or Area } \\
\text { Outside vent pipe }\end{array}$} & \multicolumn{2}{|c|}{$\alpha$ Direct $\beta \gamma$} & \multicolumn{2}{|c|}{$\alpha$ Smear $\beta \gamma$} \\
\hline & & NCD & NCD & NCD & NCD \\
\hline $6 / 19 / 98$ & HEPA filter & NCD & NCD & NCD & NCD \\
\hline $6 / 19 / 98$ & PC-5-catch basin mud & - & $<0.1$ & - & - \\
\hline $6 / 19 / 98$ & 55 gallon drum-catch basin mud & - & $<0.1^{\mathrm{d}}$ & - & - \\
\hline $6 / 22 / 98$ & Table & NCD & NCD & NCD & NCD \\
\hline $6 / 22 / 98$ & HEPA filter and housing & NCD & NCD & NCD & NCD \\
\hline $6 / 22 / 98$ & Floors & NCD & NCD & NCD & NCD \\
\hline $6 / 22 / 98$ & All walls, windows and doors & NCD & NCD & NCD & NCD \\
\hline $6 / 22 / 98$ & Spot checks of ceilings & NCD & NCD & NCD & NCD \\
\hline $6 / 22 / 98$ & $\begin{array}{l}\text { Exhaust pipe coming down } \\
\text { from ceiling }\end{array}$ & NCD & NCD & NCD & NCD \\
\hline $\begin{array}{l}\text { Final } \\
\text { Survey }\end{array}$ & $\begin{array}{l}\text { Pipes leading to water treatment } \\
\text { settling basin }\end{array}$ & NCD & NCD & NCD & $\mathrm{NCD}$ \\
\hline \multicolumn{6}{|c|}{ a $\mathrm{NCD}=$ No contamination detected. } \\
\hline \multicolumn{6}{|c|}{ b Resin was wet - no alpha reading taken. } \\
\hline \multicolumn{6}{|c|}{ c $\mathrm{dis} / \mathrm{min}-100 \mathrm{~cm}^{2}$} \\
\hline $\mathrm{d} \mathrm{mR} / \mathrm{h}$ & & & & & \\
\hline
\end{tabular}

